\title{
Contribution of selected vitamins and trace elements to immune function
}

\author{
S. Maggini ${ }^{1}$, E. S. Wintergerst ${ }^{2}$, S. Beveridge ${ }^{1}$ and D. Hornig ${ }^{3}$ \\ ${ }^{1}$ Bayer Consumer Care, Basel, Switzerland, ${ }^{2}$ Bayer Diabetes Care, Basel, Switzerland and ${ }^{3}$ Bayer Diabetes Care, \\ Reinach, Switzerland
}

The immune system requires essential nutrients to function efficiently. Inadequate intake and status of vitamins and trace elements may lead to suppressed immunity, which predisposes to infections and aggravates undernutrition. Available data indicate a role for vitamins A, $\mathrm{B}_{6}, \mathrm{~B}_{12}, \mathrm{C}, \mathrm{D}$ and $\mathrm{E}$ and folate and for the trace elements $\mathrm{Se}, \mathrm{Zn}, \mathrm{Cu}$ and $\mathrm{Fe}$ in the immune response. Evidence has accumulated that in human subjects these nutrients selectively influence the immune response, induce dysregulation of a coordinated host response to infections in the case of deficiency and oversupply, and that deficiency may impact on the virulence of otherwise harmless pathogens. Thus, micronutrients are required at appropriate intakes for the immune system to function optimally and contribute to the body's natural defences on three levels by supporting the physical barriers (skin and mucosa), cellular and humoral immunity. Vitamins A, C and E and the trace element $\mathrm{Zn}$ assist in enhancing the skin barrier function. The vitamins $\mathrm{A}, \mathrm{B}_{6}, \mathrm{~B}_{12}, \mathrm{C}, \mathrm{D}$ and $\mathrm{E}$ and folic acid and the trace elements $\mathrm{Fe}, \mathrm{Zn}, \mathrm{Cu}$ and $\mathrm{Se}$ work in synergy to support the protective activities of immune cells. Finally, all these micronutrients, except vitamin $\mathrm{C}$ and $\mathrm{Fe}$, are essential for antibody production.

The table summarises the most important roles of selected vitamins and trace elements in immune function ${ }^{(1-3)}$.

\begin{tabular}{|c|c|}
\hline Micronutrient & Main roles in the immune system \\
\hline Vitamin A & $\begin{array}{l}\text { Normal differentiation of epithelial tissue and gene expression } \\
\text { Important role both in humoral antibody response and cell-mediated immunity } \\
\text { Deficiency impairs innate immunity, induces inflammation, potentiates existing inflammatory conditions and impairs ability } \\
\text { to defend against extracellular pathogens } \\
\text { Supplementation is of benefit in reducing the morbidity and mortality from infectious diseases (especially children) }\end{array}$ \\
\hline Vitamin D & $\begin{array}{l}\text { Potent immune system modulator when metabolized to } 1,25 \text {-dihydroxycholecalciferol, is involved in cell proliferation and enhances } \\
\text { innate immunity by increasing the differentiation of monocytes to macrophages } \\
\text { Deficiency correlates with higher susceptibility to infections as a result of impaired localized innate immunity and defects in antigen } \\
\text { specific cellular immune response } \\
\text { Supplementation together with a high-Ca diet inhibits progression of autoimmune disorders }\end{array}$ \\
\hline Vitamin E & $\begin{array}{l}\text { Optimizes and enhances immune response (T-helper }(\mathrm{Th}) 1 \text { response) } \\
\text { Supplementation in healthy adults increases T-cell proliferation, improves the CD } 4+: \mathrm{CD} 8+\text {, and decreases indices of oxidative stress } \\
\text { Supplementation of elderly individuals improves overall immune function }\end{array}$ \\
\hline $\begin{array}{l}\text { Vitamins } \mathrm{B}_{6} \text { and } \mathrm{B}_{12} \\
\text { and folic acid }\end{array}$ & $\begin{array}{l}\text { Interfere with immune function through involvement in nucleic acid and protein biosynthesis } \\
\text { Maintain Th1 immune response (vitamin } \mathrm{B}_{6} \text { ), innate immunity (natural killer (NK) cell activity; folate) and act as } \\
\text { immunomodulatory for cellular immunity, especially with effects on cytotoxic cells (NK; CD8 + T lymphocytes; vitamin } \mathrm{B}_{12} \text { ) }\end{array}$ \\
\hline Vitamin $\mathrm{C}$ & $\begin{array}{l}\text { Maintains redox integrity of cells and protection against reactive oxygen species (ROS) generated during respiratory burst and inflammatory response } \\
\text { Stimulates leucocyte functions (neutrophil, monocytes movement) } \\
\text { Role in antimicrobial and NK cell activities, lymphocyte proliferation, chemotaxis and delayed-type hypersensitivity response } \\
\text { Decreases duration and severity of common cold }\end{array}$ \\
\hline $\mathrm{Se}$ & $\begin{array}{l}\text { Antioxidant essential for optimal immune response, influencing both the innate and the acquired immunity } \\
\text { Deficiency impairs antibody production and causes viruses to undergo mutations to more virulent forms } \\
\text { Supplementation normalizes age-related decline in immune response }\end{array}$ \\
\hline $\mathrm{Zn}$ & $\begin{array}{l}\text { Influences both innate and acquired immunity, supports Th1 response, helps to maintain skin and mucosal integrity } \\
\text { Deficiency leads to thymic atrophy, decreased cell-mediated cytotoxicity, helper T-cell and NK cell activities }\end{array}$ \\
\hline $\mathrm{Cu}$ & $\begin{array}{l}\text { Part of } \mathrm{Cu} / \mathrm{Zn} \text {-superoxide dismutase, a key enzyme in the defence against ROS } \\
\text { Maintains intracellular antioxidant balance, suggesting an important role in inflammatory response } \\
\text { Adequate intake supports a Th1 response and both deficiency and oversupply modulate the immune response }\end{array}$ \\
\hline $\mathrm{Fe}$ & $\begin{array}{l}\text { Essential for cell differentiation and growth, component of enzymes critical for functioning of immune cells } \\
\text { Involved in the regulation of cytokine production and action }\end{array}$ \\
\hline
\end{tabular}

Insufficient intake of micronutrients occurs in individuals with eating disorders, in smokers (both active and passive), in individuals with chronic alcohol abuse, in patients with certain diseases, during pregnancy and lactation, and in the elderly. With aging a variety of changes are observed in the immune system, which translate to less-effective innate and adaptive immune responses and increase susceptibility to infections. Overall, inadequate intake and status of vitamins $\mathrm{A}, \mathrm{B}_{6}, \mathrm{~B}_{12}, \mathrm{C}, \mathrm{D}$ and $\mathrm{E}$ and folate and of the trace elements $\mathrm{Se}, \mathrm{Zn}, \mathrm{Cu}$ and $\mathrm{Fe}$ may lead to suppressed immunity, which predisposes to infections and aggravates malnutrition. Thus, supplementation with a combination of these selected micronutrients can support the body's natural defence system by enhancing all three levels of immunity: epithelial barriers; cellular immunity; antibody production.

3. Maggini S, Wintergerst ES, Beveridge S \& Hornig DH (2007) Br J Nutr 98, Suppl. 1, S29-S35. 